\title{
The defective phosphoribosyl diphosphate synthase in a temperature-sensitive prs-2 mutant of Escherichia coli is compensated by increased enzyme synthesis
}

\author{
David A. Post, ${ }^{1,2}+$ Robert L. Switzer ${ }^{1}$ and Bjarne Hove-Jensen ${ }^{2}$ \\ Author for correspondence: Bjarne Hove-Jensen. Tel: +45 3532 2027. Fax: +453532 2040. \\ e-mail: hove@mermaid.molbio.ku.dk
}

1 Department of Biochemistry, University of Illinois, Urbana, IL 61801, USA

2 Department of Biological Chemistry, Institute of Molecular Biology, University of Copenhagen, 83H Sølvgade, DK-1307 Copenhagen K, Denmark

\begin{abstract}
An Escherichia coli strain which is temperature-sensitive for growth due to a mutation (prs-2) causing a defective phosphoribosyl diphosphate (PRPP) synthase has been characterized. The temperature-sensitive mutation was mapped to a 276 bp HindIII-BssHII DNA fragment located within the open reading frame specifying the PRPP synthase polypeptide. Cloning and sequencing of the mutant allele revealed two mutations. One, a $G \rightarrow A$ transition, located in the ninth codon, was responsible for the temperatureconditional phenotype and resulted in a serine residue at this position. The wild-type codon at this position specified a glycine residue that is conserved among PRPP synthases across a broad phylogenetic range. Cells harbouring the glycine-to-serine alteration specified by a plasmid contained approximately $50 \%$ of the PRPP synthase activity of cells harbouring a plasmid-borne wildtype allele, both grown at $25^{\circ} \mathrm{C}$. The mutant enzyme had nearly normal heat stability, as long as it was synthesized at $25^{\circ} \mathrm{C}$. In contrast, there was hardly any PRPP synthase activity or anti-PRPP synthase antibody cross-reactive material present in cells harbouring the glycine to serine alteration following temperature shift to $42^{\circ} \mathrm{C}$. The other mutation was a $\mathrm{C} \rightarrow \mathrm{T}$ transition located 39 bp upstream of the $G \rightarrow A$ mutation, i.e. outside the coding sequence and close to the Shine-Dalgarno sequence. Cells harbouring only the $C \rightarrow T$ mutation in a plasmid contained approximately three times as much PRPP synthase activity as a strain harbouring a plasmid-borne wild-type prs allele. In cells harbouring both mutations, the $\mathrm{C} \rightarrow \mathrm{T}$ mutation appeared to compensate for the $\mathbf{G} \rightarrow$ A mutation by increasing the amount of a partially defective enzyme at the permissive temperature.
\end{abstract}

Keywords: phosphoribosylpyrophosphate, PRPP synthase, RNA analysis, nucleotide synthesis, prs gene

\section{INTRODUCTION}

In Escherichia coli the compound 5-phospho- $\alpha$-D-ribose 1diphosphate (phosphoribosylpyrophosphate, PRPP) is a precursor in the biosynthesis of the purine, pyrimidine and pyridine nucleotides, as well as the amino acids histidine and tryptophan (Hove-Jensen, 1988, 1989). The

†Present address: Abbott Laboratories, Strain Development Department, 1401 Sheridan Road, North Chicago, IL 60064, USA.

Abbreviation: PRPP, 5-phospho- $\alpha$-D-ribose 1-diphosphate. synthesis of PRPP is catalysed by PRPP synthase (ribosephosphate pyrophosphokinase, EC 2.7.6.1): ribose-5phosphate + ATP $\rightarrow$ PRPP + AMP. The gene specifying PRPP synthase of E. coli and Salmonella typhimurium, designated prs, has been the subject of extensive analysis. The gene from both organisms has been mapped (HoveJensen, 1983; Jochimsen et al., 1985), cloned and sequenced (Bower et al., 1988; Hove-Jensen, 1985; HoveJensen et al., 1986). In S. typhimurium two mutants have been isolated by a physiological selection (Jochimsen $e t$ al., 1985) or by screening mutants for temperaturesensitive PRPP synthase activity (Pandey \& Switzer, 
Table 1. Bacterial strains

\begin{tabular}{|c|c|c|}
\hline Strain & Genotype & Source/construction \\
\hline HO336 & $\operatorname{ara} C_{\mathrm{am}} \operatorname{araD} \Delta(l a c) U 169 \operatorname{trp} p_{\mathrm{am}} \operatorname{rps} L \operatorname{rel} A$ thi & Silhavy et al. (1984) \\
\hline $\mathrm{HO} 340$ & $\operatorname{ara} C_{\mathrm{am}} \operatorname{araD} \Delta(l a c) U 169 \operatorname{trp} \mathrm{am}$ rpsL relA thi supF & $\begin{array}{l}\text { Nilsson \& Hove-Jensen } \\
(1987)\end{array}$ \\
\hline HO371 & $\operatorname{ara} C_{\mathrm{am}} \operatorname{araD} \Delta(l a c) U 169 \operatorname{trp} p_{\mathrm{am}} \operatorname{rpsL} \operatorname{rel} A$ thi supF bem $A$ & $\begin{array}{l}\text { Nilsson \& Hove-Jensen } \\
\text { (1987) }\end{array}$ \\
\hline $\mathrm{HO} 447$ & supF rel $A$ spo $T$ rpsL lamB met $B$ purE $q b c:: \operatorname{Tn} 10$ deoD gsk-3 & Hove-Jensen (1989) \\
\hline HO449 & $\begin{array}{l}\text { supF } \operatorname{rel} A \text { spoT } r p s L \text { lam } B \text { met } B \text { deoD udp gsk-3 pnc } A \text { bem } A \\
\text { zjj::Tn } 10\end{array}$ & HO650 $\times$ P1 $\left(\right.$ Sø1390), Tet $^{r}$ \\
\hline HO497 & $\begin{array}{l}\text { recB21 recC22 sbcB15 thr leu proA2 bisG argE thi rpsL } \\
\text { zjj:: } \operatorname{Tn} 10 \mathrm{deo} D\end{array}$ & JC7623 $\times$ P1(HO449), Tet ${ }^{r}$ \\
\hline HO498 & 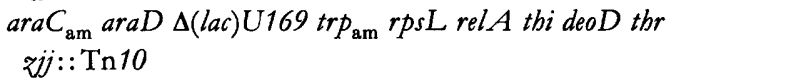 & $\mathrm{HO} 336 \times \mathrm{P} 1(\mathrm{HO} 497), \mathrm{Tet}^{\mathrm{r}}$ \\
\hline HO499 & $\operatorname{ara} C_{\mathrm{am}} \operatorname{araD} \Delta(l a c) U 169 \operatorname{trp}_{\mathrm{am}} r p s L$ relA thi deoD & HO498 $\times$ P1(HO605), $\mathrm{Thr}^{+}$ \\
\hline HO500 & $\begin{array}{l}\operatorname{ara} C_{\mathrm{am}} \operatorname{araD} \Delta(l a c) U 169 \operatorname{trp} p_{\mathrm{am}} r p s L \text { relA thi deoD purE gsk-3 } \\
2 b b: \operatorname{Tn} 10\end{array}$ & $\mathrm{HO} 499 \times \mathrm{P} 1(\mathrm{HO} 447), \mathrm{Tet}^{\mathrm{r}}$ \\
\hline HO541 & $\begin{array}{l}\text { metB bis } \operatorname{trp}_{\mathrm{am}} l e u_{\mathrm{am}} l a c Z_{\mathrm{am}} g a l K_{\mathrm{am}} g a l E \text { rpsL sueB sueC } \\
\text { supD } D 3,74 \text { prs-2 }\end{array}$ & Hove-Jensen (1985) \\
\hline $\mathrm{HO} 600$ & $\operatorname{ara} C_{\mathrm{am}} \operatorname{araD} \Delta(l a c) U 169 \operatorname{trp}_{\mathrm{am}} r p s L$ rel $A$ thi deoD gsk-3 & HO500 $\times$ P1(HO605), Pur ${ }^{+}$ \\
\hline HO605 & $\begin{array}{l}\sup F \text { rel } A \text { spoT rpsL lamB metB deoD udp:: } \operatorname{Tn} 5 \text { gsk-3 pnc } A \\
\operatorname{bem} A\end{array}$ & Hove-Jensen (1988) \\
\hline HO608 & supF relA spoT rpsL lamB metB deoD udp:: Tn5 gsk-3 pnc $A$ & Hove-Jensen (1989) \\
\hline HO609 & $\begin{array}{l}\text { supF rel } A \text { spoT } r p s L \text { lamB metB deoD udp:: Tn5 gsk-3 pnc } A \\
\text { prs-2 }\end{array}$ & Hove-Jensen (1988) \\
\hline HO611 & $\operatorname{ara} C_{\mathrm{am}} \operatorname{araD} \Delta($ lac $) U 169 \operatorname{trp} \mathrm{am}$ rpsL relA thi supF prs-2 & $\mathrm{HO} 371 \times \mathrm{P} 1(\mathrm{HO} 541), \mathrm{Hem}^{+}$ \\
\hline HO650 & supF rel $A$ spo $T$ rpsL lamB metB $\operatorname{deo} D$ udp gsk-3 pnc $A$ bem $A$ & Hove-Jensen (1989) \\
\hline HO697 & $\begin{array}{l}\operatorname{ara} C_{\mathrm{am}} \operatorname{araD} \Delta(\text { lac }) U 169 \operatorname{tr} p_{\mathrm{am}} \operatorname{rps} L \text { rel } A \text { thi deoD gsk-3 } \\
\text { udp::Tn5 }\end{array}$ & $\mathrm{HO} 600 \times \mathrm{P} 1(\mathrm{HO} 605), \mathrm{Kan}^{\mathrm{r}}$ \\
\hline HO700 & $\begin{array}{l}\text { supF rel } A \text { spoT } r p s L \text { lamB met } B \text { deoD udp gsk-3 pnc } A \\
\Delta(p r s-3):: K a n^{r}\end{array}$ & Hove-Jensen (1989) \\
\hline HO728 & $\begin{array}{l}\text { supF rel } A \text { spoT } r p s L \text { lam B metB deoD udp gsk-3 pnc } A \\
\Delta(p r s-4):: \operatorname{Kan}^{\mathrm{r}}\end{array}$ & Hove-Jensen (1989) \\
\hline HO764 & $\operatorname{ara} C_{\mathrm{am}} \operatorname{araD} \Delta($ lac $) U 169 \operatorname{tr} p_{\mathrm{am}} r p s L$ relA thi deoD gsk-3 udp & $\mathrm{HO} 765 \times \mathrm{P} 1(\mathrm{~S} ø 928), \mathrm{Ilv}^{+}$ \\
\hline HO765 & $\operatorname{ara} C_{\mathrm{am}} \operatorname{araD} \Delta(l a c) U 169 \operatorname{trp} \mathrm{am}$ rpsL rel $A$ thi deoD gsk-3 ilvD & HO697 $\times$ P1(PS1500), $\mathrm{Udp}^{+}$ \\
\hline HO770 & $\begin{array}{l}\operatorname{ara} C_{\mathrm{am}} \operatorname{araD} \Delta(\text { lac }) U 169 \operatorname{trp} \mathrm{am} \\
\text { udp }\end{array}$ & HO764 × P1(HO340), $\operatorname{Trp}^{+}$ \\
\hline HO773 & $\begin{array}{l}a r a C_{\mathrm{am}} \text { araD } \Delta(\text { lac }) U 169 \operatorname{trp}_{\mathrm{am}} \text { rpsL relA thi supF udp deoD } \\
g s k-3 \Delta(p r s-4):: \mathrm{Kan}^{\mathrm{r}}\end{array}$ & $\mathrm{HO} 770 \times \mathrm{P} 1(\mathrm{HO} 728), \mathrm{Kan}^{\mathrm{r}}$ \\
\hline JC7623 & recB21 recC22 sbcB15 thr leu proA2 bisG argE thi rpsL & Kushner et al. (1971) \\
\hline JM83 & ara $\Delta($ lac-pro $A B)$ rpsL thi $\phi 80 d$ lac $Z \Delta M 15$ & Yanisch-Perron et al. (1985) \\
\hline PS1500 & ilvD pro met $B$ argH thi lac gal mal rpsL supE rim $C$ & CGSC* \\
\hline Sø928 & $\Delta(d e o C A B D) \Delta($ lac $)$ thi upp udp ton & $\begin{array}{l}\text { Valentin-Hansen } \text { et al. } \\
\text { (1978) }\end{array}$ \\
\hline Sø1390 & leu thi zij:: $\operatorname{Tn} 10$ & K. Hammer† \\
\hline
\end{tabular}

*CGSC, E. coli Genetic Stock Center, Yale University, Connecticut, USA.

† K. Hammer, Danish Technical University.

1982; Post \& Switzer, 1991). In E. coli a number of prs mutants have been isolated and characterized. They include a mutant with altered kinetic properties of PRPP synthase (Bower et al., 1989; Hove-Jensen \& Nygaard, 1982 ) and genetically engineered prs deletion mutations constructed in vitro and subsequently transferred to the chromosome by homologous recombination (HoveJensen, 1988, 1989). In addition, a mutant that is temperature-sensitive for growth due to a mutation in the prs gene has been isolated and characterized. The mutant allele responsible for the conditional growth is designated prs-2(Hove-Jensen, 1985). This mutant strain was isolated by localized mutagenesis of the prs region of the chromosome following the preparation of a bacteriophage P1 lysate in a mutD-mutator strain and transfer of the mutagenized DNA to the E. coli chromosome by trans- 
duction. This report presents an analysis of the biochemical nature of the prs- 2 mutation.

\section{METHODS}

Bacterial strains, growth conditions and plasmid vectors. The $E$. coli strains used, and their derivation or source, are given in Table 1. Strains which harbour prs null mutations $(\Delta p r s-3$ or $\Delta p r s-4)$ are viable provided that guanosine, uridine, histidine, tryptophan and NAD are added to the growth medium (HoveJensen, 1989), whereas strains harbouring the $p r s-2_{\mathrm{ts}}$ allele can be maintained at $25^{\circ} \mathrm{C}$ without these additions (Hove-Jensen, 1988). Growth media were either LB medium (Miller, 1972) or AB minimal salts medium (Clark \& Maaløe, 1967). The carbon source was glucose $(0 \cdot 2 \%)$. Thiamin $\left(1 \mathrm{mg} \mathrm{l}^{-1}\right)$ was added routinely to all minimal media. When necessary, compounds were added to the following final concentrations: amino acids to $50 \mathrm{mg} \mathrm{l}^{-1}$ each; uridine and guanosine to $40 \mathrm{mg} \mathrm{l}^{-1}$ each. NAD was added to both $\mathrm{LB}$ and minimal media at $40 \mathrm{mg} \mathrm{l}^{-1}$. Transduction was performed as described by Miller (1972). Plasmids were selected and maintained by the presence of ampicillin, $50 \mathrm{mg} \mathrm{l}^{-1}$. Kanamycin and tetracycline were used at concentrations of 30 and $10 \mathrm{mg} \mathrm{l}^{-1}$, respectively. pBR322 was used as a plasmid vector (Bolivar et al., 1977).

Manipulation of nucleic acids. Procedures for the isolation of chromosomal DNA as well as plasmid DNA either on a small scale for screening or by buoyant-density centrifugation in $\mathrm{CsCl}$ gradients containing ethidium bromide, have been previously described (Birnboim \& Doly, 1979; Sambrook et al., 1989; Silhavy et al., 1984). Transformation with plasmid DNA was performed as described by Mandel \& Higa (1970). Restriction endonucleases were used as recommended by the suppliers (Boehringer Mannheim, Promega or New England Biolabs). Calf intestinal alkaline phosphatase and T4 DNA ligase were from Boehringer Mannheim. DNA fragments were isolated with the Gene Clean kit (Bio-101). Methods for Southern blot analysis (Sambrook et al., 1989) and nucleotide sequencing (Post et al., 1993; Sanger et al., 1977) have been described previously. Procedures for the isolation of RNA, blotting of RNA onto nylon membranes, and hybridization with ${ }^{32} \mathrm{P}$-labelled RNA probes, have been described previously (Post et al., 1993).

Western blot analysis. The antibody preparation used was raised in a rabbit against highly purified S. typhimurium PRPP synthase (Post \& Switzer, 1991). Cross-reactive material was determined by immunoblotting employing ${ }^{125} \mathrm{I}$-protein $\mathrm{A}$, according to the general procedure of Grandoni et al. (1989).

Enzyme assays. PRPP synthase activity was determined by the ${ }^{32}$ P-transfer assay (Switzer \& Gibson, 1978) with the modifications described previously (Bower et al., 1988), except that the concentrations of the substrates were: $5 \mathrm{mM}$ ribose 5-phosphate and $3 \mathrm{mM}$ ATP. The $\mathrm{Mg}^{2+}$ concentration was $5 \mathrm{mM} . \beta$ Lactamase was assayed with cephaloridine as the substrate as previously described (Lupski et al., 1984). The change in absorbance was monitored at $255 \mathrm{~nm}$. Protein concentration was determined by the bicinchoninic acid procedure with chemicals provided by Pierce (Smith et al., 1985).

\section{RESULTS}

\section{Mapping of the temperature-sensitive lesion of prs-2}

To map the lesion responsible for the temperaturesensitive growth of strain HO611 (prs-2) a series of prs non-complementing plasmids, containing deletions extending into the prs gene from either end of the coding sequence, was transformed into the prs- 2 strain followed (a)

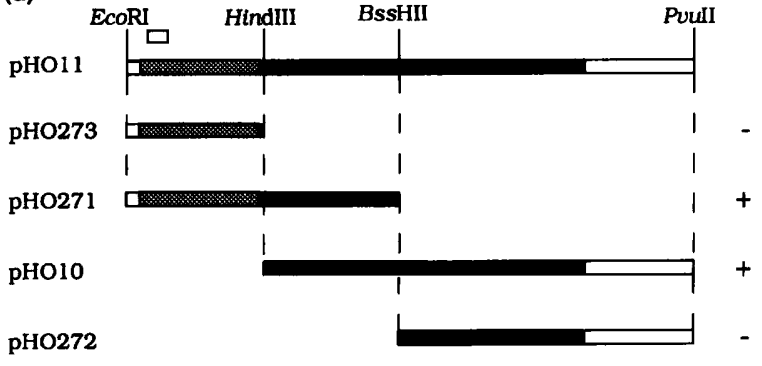

(b) SPhI MStII
495-GCATGCCTGAGGTTCTTCTCGTGCCTGATATGAAGCTITTTGCTGGTAACGCC-547
T
MetProAspMetLysLeuPheAlaGlyAsnAla

(c)

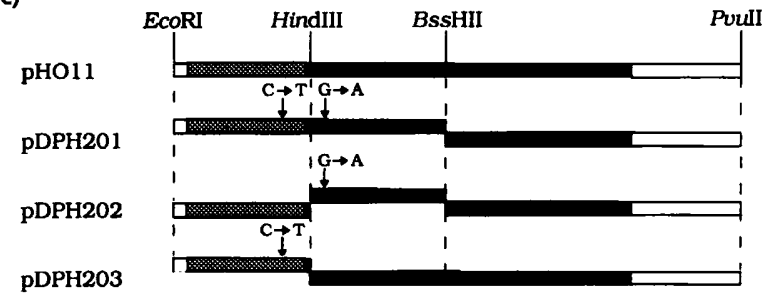

Fig. 1. Characterization of the prs-2 allele. (a) Mapping of the temperature-sensitive lesion. A restriction map of pHO11 (HoveJensen, 1985) is shown at the top. Below are indicated the structure of the inserts of the plasmids pHO273, pHO271, pHO10 and pHO272, which were constructed as follows: pHO273 was constructed by digestion of pHO11 DNA with HindIII, followed by $S 1$ nuclease treatment, Pvull digestion and ligation; pHO271 was constructed by digestion of pHO11 DNA with BssHII, S1 nuclease and Pvull followed by ligation; pHO272 was obtained by digestion of pHO11 DNA with ECORI and BssHII, followed by S1 nuclease digestion and ligation; pHO10 was described before (Hove-Jensen, 1985). The coding sequence of the prs gene is shown as a black region, the promoter and leader regions are shaded, and flanking sequences are unshaded. On the right is indicated the ability of each plasmid to provide, by homologous recombination, a temperatureresistant prs allele following transformation of strain HO611 (prs-2 $\left.t_{t s}\right):+$, ability to give temperature-resistant recombinants; - , inability to give temperature-resistant recombinants. (b) Nucleotide sequence of the prs-2 allele. The stretch of nucleotides constitutes the wild-type sequence, with numbers referring to the previously published sequence (Hove-Jensen et al., 1986). The amino acid sequence of the $\mathrm{N}$-terminal end of the PRPP synthase subunit is shown below the nucleotide sequence. The two nucleotide alterations are given immediately below the wild-type nucleotide sequence, as well as the resulting alteration of the amino acid specified by the ninth codon. The Shine-Dalgarno sequence is underlined. Relevant restriction recognition sites are shown. (c) Separation of the two mutations of the prs-2 allele. The structure of pHO11 with relevant restriction endonuclease recognition sites is shown at the top. The designation of the different regions is the same as that used in (a). The point mutations found in prs- 2 are indicated. The DNA fragments containing the mutations were subcloned from pDPH200 (prs-2) into pHO11 (similarly digested), to make a series of isogenic plasmids harbouring functional prs alleles with none, one or both of the point mutations as follows: pDPH201 contained the EcoRI-BssHII DNA fragment from pDPH200; pDPH202 contained the HindIII-BssHII DNA fragment from PDPH200; and PDPH203 contained the EcoRI-HindIII DNA fragment from pDPH200. 
Table 2. PRPP synthase and $\beta$-lactamase activities in strains harbouring plasmids with various prs mutations

The data are from one experiment. Enzyme activities varied less than $20 \%$ in duplicate experiments. ND, Not determined.

\begin{tabular}{|c|c|c|c|c|c|}
\hline \multirow[t]{2}{*}{ Plasmid* } & \multirow[t]{2}{*}{$\begin{array}{c}\text { Mutation(s) } \\
\text { present }\end{array}$} & \multirow[t]{2}{*}{$\begin{array}{c}\text { Growth } \\
\text { temp. }\left({ }^{\circ} \mathrm{C}\right)\end{array}$} & \multicolumn{2}{|c|}{$\begin{array}{l}\text { PRPP synthase } \\
\text { activity }\left[\mu \mathrm{mol} \mathrm{min}^{-1}\right. \\
{\left.\text { (mg protein })^{-1}\right] \dagger}^{-1}\end{array}$} & \multirow{2}{*}{$\begin{array}{c}\beta \text {-Lactamase } \\
\text { activity } \ddagger \\
{\left[\Delta A_{255} \min ^{-1}(\mathrm{mg}\right.} \\
\left.\text { protein })^{-1}\right]\end{array}$} \\
\hline & & & $25^{\circ} \mathrm{C}$ & $42{ }^{\circ} \mathrm{C}$ & \\
\hline \multirow[t]{2}{*}{ pHO11 } & None & 25 & 0.76 & 3.6 & $2 \cdot 2$ \\
\hline & & 42 & 1.60 & $9 \cdot 1$ & 3.6 \\
\hline \multirow[t]{2}{*}{ pDPH201 } & $\mathrm{C} \rightarrow \mathrm{T}, \mathrm{G} \rightarrow \mathrm{A}$ & 25 & 1.73 & $5 \cdot 7$ & $2 \cdot 1$ \\
\hline & & 42 & $0 \cdot 05$ & $0 \cdot 13$ & $3 \cdot 0$ \\
\hline \multirow[t]{2}{*}{ pDPH202 } & $\mathrm{G} \rightarrow \mathrm{A}$ & 25 & 0.39 & $1 \cdot 1$ & $2 \cdot 1$ \\
\hline & & 42 & 0.04 & $0 \cdot 10$ & $3 \cdot 5$ \\
\hline \multirow[t]{2}{*}{ pDPH203 } & $\mathrm{C} \rightarrow \mathrm{T}$ & 25 & $2 \cdot 57$ & ND & 1.5 \\
\hline & & 42 & $2 \cdot 58$ & ND & $3 \cdot 7$ \\
\hline
\end{tabular}

* The host strain was HO700 ( $\Delta$ prs-3). Cells were grown in LB supplemented with guanosine, uridine and NAD.

† PRPP synthase activity was determined at the temperature indicated as described in Methods.

$\ddagger \beta$-Lactamase activity was determined at $37^{\circ} \mathrm{C}$ as described in Methods.

by a simultaneous selection for antibiotic-resistant and temperature-resistant $\left(42^{\circ} \mathrm{C}\right)$ recombinants, i.e. a selection for a wild-type prs allele. Thus, a plasmid with an insert which straddles the mutation causing the temperature-sensitive phenotype was expected to result in recombinants that were cured of this defect, whereas an insert which covered regions outside the mutation would be unable to cure the temperature defect. From the results given in Fig. 1(a), it appears that the lesion responsible for the temperature-sensitive phenotype was located between the HindIII and BssHII restriction endonuclease recognition sites, i.e. a DNA fragment $276 \mathrm{bp}$ in length. As expected, this location was within the open reading frame specifying the PRPP synthase polypeptide.

\section{Cloning of the prs-2 mutant allele}

Southern blotting of DNA isolated from strain HO611 (prs-2) and hybridization with prs DNA as a probe revealed that the $p r s-2$ allele was located in a $2.3 \mathrm{~kb}$ DNA fragment generated by EcoRI (data not shown). This was expected from the restriction maps previously published (Hove-Jensen, 1985; Kohara et al., 1987). Chromosomal DNA was then isolated from strain HO611 (prs-2) and digested by EcoRI, followed by fragment separation by agarose gel electrophoresis. A gel piece containing DNA fragments of $2 \cdot 1-2 \cdot 5 \mathrm{~kb}$ was excised and the DNA was purified. The fragments were ligated to $\mathrm{pBR} 322 \mathrm{DNA}$ that had been previously digested by EcoRI. Ligation products were amplified in strain JM83, and plasmid DNA was extracted from the pooled transformants and used to transform strain $\mathrm{HO} 773$ (Aprs-4) to $\mathrm{Prs}^{+}$at $25^{\circ} \mathrm{C}$. One isolate, pDPH200, was used for further analysis.

\section{Characterization of the prs-2 allele}

To determine the mutations in the isolated plasmids containing the prs-2 allele, the region encompassing the EcoRI to BssHII restriction sites in pDPH200 was sequenced (Fig. 1b). Two mutations were found in the DNA, one at bp $500(\mathrm{C} \rightarrow \mathrm{T})$ and another at bp $539(\mathrm{G} \rightarrow$ A), with numbers referring to the previously published sequence (Hove-Jensen et al., 1986). The first mutation was $3 \mathrm{bp}$ upstream of the Shine-Dalgarno sequence (Shine \& Dalgarno, 1974); the second was the first base of the ninth codon and changed the glycine codon to a serine codon. Since the prs- 2 allele had a temperature-sensitive phenotype, we wanted to determine which of these mutations was responsible for the temperature sensitivity, and plasmids were constructed that contained either one or both of the mutations. Fortuitously there was a unique HindIII recognition site between the two mutations, which were separated by only $38 \mathrm{bp}$, facilitating the construction of the plasmids pDPH201, 202 and 203 (Fig. 1c). Strain HO700 ( $\Delta$ prs-3) harbouring each of these plasmids was grown at both 25 and $42{ }^{\circ} \mathrm{C}$, and the cells were harvested in the exponential growth phase. The PRPP synthase activity in each plasmid-harbouring strain was then determined (Table 2). $\beta$-Lactamase activities were also determined to assess relative plasmid copy number. Both of the mutations had a substantial effect on the amount of PRPP synthase activity in the cell. When only the upstream mutation $(\mathrm{C} \rightarrow \mathrm{T})$ was present, about 3.4-fold more PRPP synthase activity was present at $25^{\circ} \mathrm{C}$ compared to that present in the wild-type. On the other hand, the presence of only the downstream mutation reduced the level of PRPP synthase activity to about $50 \%$ of the wild-type activity. When both mutations were 


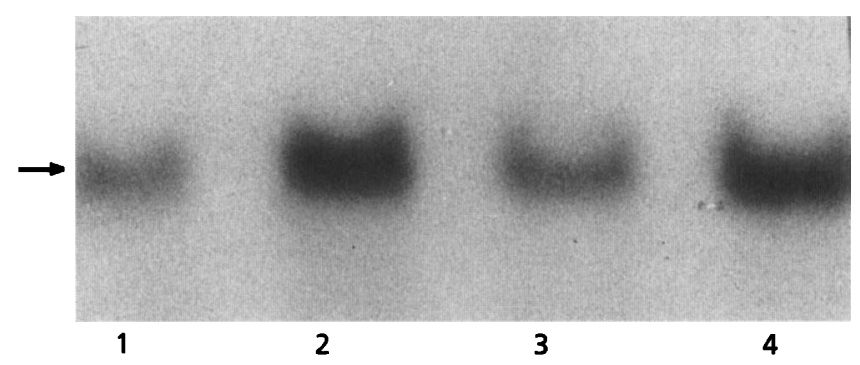

Fig. 2. Northern blot analysis of prs ${ }^{+}$- and prs-2-specified mRNA transcripts. Five micrograms of RNA was loaded in each lane, electrophoresed and blotted as described in Methods. The blot was hybridized with a probe of the $E$. coli prs gene. The arrow indicates the $1300 \mathrm{nt}$ prs-specified transcript. RNA was purified from a wild-type strain (HO608, lanes 1 and 3) and a prs-2 strain (HO609, lanes 2 and 4) grown at $25^{\circ} \mathrm{C}$ (lanes 1 and 2), or $42^{\circ} \mathrm{C}$ (lanes 3 and 4).

present, the downstream mutation was epistatic to the upstream mutation, i.e. the downstream mutation reduced the activity produced by the upstream mutation - compare plasmids $\mathrm{pDPH} 201$ with $\mathrm{pDPH} 203$ grown at $25^{\circ} \mathrm{C}$ - but the PRPP synthase activity was still about double that of the wild-type (pHO11) grown at $25^{\circ} \mathrm{C}$. This analysis also showed that the temperature-sensitivity of this PRPP synthase was caused by the downstream mutation located within the PRPP synthase reading frame (plasmids pDPH201 and pDPH202 compared with pHO11 and pDPH203 grown at 25 and $42^{\circ} \mathrm{C}$; Table 2). As shown previously for the chromosomal prs-2 allele (Hove-Jensen, 1988), the plasmid-borne prs-2 allele conferred temperature-sensitivity upon the host strain in vivo. Cells deleted for the chromosomal prs gene and harbouring a plasmid-borne prs-2 allele were still able to grow at an elevated temperature $\left(38^{\circ} \mathrm{C}\right)$, but the amount of PRPP synthase was 30 -fold lower than that of the same cells grown at $25^{\circ} \mathrm{C}$ (data not shown). Since the mutation conferring temperature sensitivity was mapped to the polypeptide coding region, we would predict that the protein itself would be temperature-labile. However, if an extract of strain HO700 ( $\Delta$ prs-3), bearing a plasmid with the prs-2 allele, was prepared from cells grown at $25^{\circ} \mathrm{C}$, and assayed for PRPP synthase activity at $42{ }^{\circ} \mathrm{C}$, the prs2 -specified enzyme activity was almost as stable as the wild-type enzyme. Wild-type PRPP synthase activity increased four- to fivefold as the assay temperature was increased from 25 to $42{ }^{\circ} \mathrm{C}$, whereas the prs-2-specified mutant enzyme activity increased by approximately threefold (Table 2: pDPH201 compared with pHO11). Thus, the mutant enzyme that had been synthesized at $25^{\circ} \mathrm{C}$ appeared almost as stable in vitro as the wild-type enzyme.

\section{Effects of temperature on the transcription and translation of the prs-2 allele}

Since the prs-2 allele was a double mutation and one of the mutations was outside the coding sequence, we wished to determine if prs transcription or translation was altered in the prs-2 strain. To investigate this possibility, prs mRNA was analysed by Northern blot analysis and PRPP

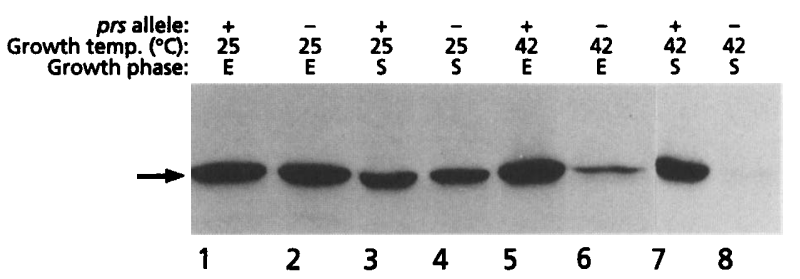

Fig. 3. Western immunoblot analysis of $E$. coli prs ${ }^{+}$(HO608) and prs-2 (HO609) strains. Western immunoblot analysis was carried out with $50 \mu \mathrm{g}$ of crude extract from wild-type and mutant strains harvested in exponential and early stationary phases, from cultures grown at both 25 and $42{ }^{\circ} \mathrm{C}$. Above each lane is indicated which strain was analysed $(+$, wild-type;,- prs-2), and the temperature and phase of growth ( $E$, exponential; $S$, stationary) during which the sample was harvested. Both strains were initially grown at $25^{\circ} \mathrm{C}$ (lanes 1-4); then a portion from each culture in stationary phase was inoculated into fresh medium at $42{ }^{\circ} \mathrm{C}$. Samples were harvested from the $42^{\circ} \mathrm{C}$ cultures in the exponential phase (lanes 5 and 6); and the stationary phase (lanes 7 and 8). The arrow indicates position of PRPP synthase.

synthase synthesis was analysed by Western immunoblot analysis with RNA and protein isolated from strains HO608 $\left(p r s^{+}\right)$and HO609 (prs-2). The results of the Northern analysis indicated that the prs-2 strain contained two- to threefold more prs-specific transcript (Fig. 2) than the wild-type strain at 25 and $42{ }^{\circ} \mathrm{C}$, respectively. Moreover, there was apparently no reduction in the amount of prs-2-specified mRNA in cells grown at $42^{\circ} \mathrm{C}$ as compared to those grown at $25^{\circ} \mathrm{C}$. Thus, the temperature-sensitivity of cells harbouring prs- 2 was not caused by a temperaturesensitive transcription process.

The results of Western immunoblot analysis of extracts from strains HO608 and HO609 are shown in Fig. 3. It appeared that almost identical amounts of cross-reactive material were present in $p r s^{+}$and prs-2 cells grown at $25^{\circ} \mathrm{C}$. This was the case whether the cells were harvested in the exponential or in the stationary growth phase (Fig. 3 , lanes 1-4). However, when cells were harvested several doubling times after a temperature shift to $42^{\circ} \mathrm{C}$, the amount of cross-reactive material in the prs-2 strain was greatly reduced and eventually virtually undetectable, whereas the amount of cross-reactive material in the $\mathrm{prs}^{+}$ strain was hardly altered (Fig. 3, lanes 5-8). It is noteworthy that although the prs-2 strain apparently contained more prs-specific transcript than the $p^{+} s^{+}$strain at $25^{\circ} \mathrm{C}$, it still had approximately the same amount of anti-PRPP synthase cross-reactive material as the wildtype (Fig. 3, lanes 1 and 2). Both cross-reactive material and enzyme activity were detected at greatly reduced levels in the prs-2 strain following the temperature shift to $42{ }^{\circ} \mathrm{C}$. This result indicated that the mutant enzyme was labile and possibly rapidly degraded at the elevated temperature.

\section{DISCUSSION}

Two separate point mutations were identified in the prs-2 allele. The first mutation was located 3 bp upstream of the Shine-Dalgarno sequence. This mutation, a $\mathrm{C} \rightarrow \mathrm{T}$ tran- 


\begin{tabular}{|c|c|}
\hline c. & MPDMKLFAGNATPELAQRIANRLYTSLGDAAVGRFSDGEVSVQI \\
\hline & MPDMKLFAGNATPELAQRIANRLYTSLGDAAVGRFSDGEVSVQ I \\
\hline & MSNQYGDKNLKIFSLNSNPELAKEIADIVGVQLGKCSVTRFSDGEVQINI \\
\hline t. & KSVNRTNTRLKLFSGTANPALAQEIAWYMGLDLGKVNIKRFADGEIYVQL \\
\hline d. & TEKRDYSRPFCLVSGNGNRPLAEAVALLMGTHTHHTSVTOYSNGEVNVRI \\
\hline & MPNIKVFSGSSHPDLSTRICERLQLEVSKASLKKFFSNKETNVEI \\
\hline $\mathrm{HI} / \mathrm{HIII} / \mathrm{RI}$ & MPNIKIFSGSSHQDLSQKIADRLGLELGKVVTKKFSNQETCVEI \\
\hline I I & MPNIVLFSGSSHQDLSQRVADRLGLELGKVVTKKFSNQETSVEI \\
\hline & LGLELGKVVTKK \\
\hline
\end{tabular}

Fig. 4. Comparison of $\mathrm{N}$-terminal sequences of PRPP synthases of various organisms. The sequences are aligned to give the highest degree of homology. Numbers to the right indicate the amino acid position of the residue at the right-hand end of each line. Abbreviations: $E$. C., E. coli (Hove-Jensen et al., 1986); S. t., S. typhimurium (Bower et al., 1988); B. s., Bacillus subtilis (Nilsson et al., 1989); A. t., Arabidopsis thaliana (B. N. Krath \& B. Hove-Jensen, EMBL accession no. X83764); L. d., Leishmania donovani (Hendrickson et al., 1993); C. e., Caenorhabditis elegans (R. Wilson and others, GenBank accession no. U00036.); HI, HII and HIII, human PRPP synthase I, II and III, respectively (Roessler et al., 1990; Taira et al., 1990); RI and RII, rat PRPP synthase I and II, respectively (Taira et al. 1987). All the sequences are deduced from nucleotide sequences. The $E$. coli and $S$. typhimurium sequences have also been determined by automated Edman degradation (Harlow \& Switzer, 1990; HoveJensen et al., 1986). The $L$. donovani enzyme has a 37 amino acid extension and the $A$. thaliana enzyme a 32 amino acid extension at their $\mathrm{N}$-terminal ends, which are not shown. The sequences of human PRPP synthases I and III, as well as rat PRPP synthase $I$ are identical within the segment shown. Filled circles indicate positions with identical amino acid among all the sequences; open circles indicate positions with conservative replacements.

sition, apparently did not create a better complementarity to the 16S rRNA sequence. Yet a strain carrying a plasmid-borne copy of this point mutation contained 3.4fold more PRPP synthase activity than the same strain carrying the wild-type allele on an identical plasmid. Although the mechanism by which this mutation increased the synthesis of PRPP synthase remains unknown, it is possible that it improved ribosome binding by sequences in addition to the Shine-Dalgarno sequence. The second mutation was a $G \rightarrow A$ transition, which was situated in the ninth codon and resulted in the conversion of a glycine residue of the wild-type to a serine residue. This mutation was solely responsible for the temperaturesensitivity of the prs-2 allele and was detrimental to production of the enzyme. A plasmid-borne copy of the latter mutation produced only about half as much PRPP synthase activity as was formed in cells carrying the wildtype gene on an identical plasmid. It was also observed that the downstream mutation was epistatic to the upstream mutation. That is, the downstream mutation caused a decrease in the amount of enzyme produced, when the upstream mutation was also present, from 3.4to only 2-fold over wild-type PRPP synthase synthesis in cells grown at $25^{\circ} \mathrm{C}$. Also, the presence of the downstream mutation resulted in a temperature-sensitive phenotype, whether the upstream mutation was present or not. When a prs-2 strain was grown at $25^{\circ} \mathrm{C}$, the PRPP synthase formed was almost as stable at $42^{\circ} \mathrm{C}$ in vitro as the wild-type enzyme at $42{ }^{\circ} \mathrm{C}$. However, Western immunoblots of crude extracts of a prs- 2 strain that had been grown at $42{ }^{\circ} \mathrm{C}$ showed very little cross-reactive material. The simplest explanation for the lack of mutant PRPP synthase protein at $42^{\circ} \mathrm{C}$ is degradation of the enzyme, although failure to synthesize the protein at $42{ }^{\circ} \mathrm{C}$ cannot be excluded. We believe that the $\mathrm{G} \rightarrow \mathrm{A}$ transition within the coding sequence appeared due to the screening procedure, i.e. temperature-sensitivity, and that the $\mathrm{C} \rightarrow$ $\mathrm{T}$ transition appeared subsequently to compensate for a malfunctioning enzyme. Consequently, separation of the two mutations on the chromosome might result in the appearance of other secondary mutations. The separation of the two specific mutations as well as the analysis of their phenotypes was therefore performed on plasmids.

The function of various amino acid residues in PRPP synthases has been studied to some extent. The glycine residue that is altered by the prs-2 allele is highly conserved, as indicated by the amino acid comparison shown in Fig. 4. All the PRPP synthase sequences, including those from Gram-negative and Gram-positive bacteria and various eukaryotic organisms, have a glycine residue at this position, except for Bacillus subtilis, which has a leucine residue. This conservation indicates an important function of the glycine residue, most likely in maintaining the structure of the polypeptide. It is therefore conceivable that the mutant enzyme did not fold correctly when it was synthesized at the restrictive temperature. Another indication of the importance of the $\mathrm{N}$-terminal segment of PRPP synthase in maintaining the stability of the enzyme comes from the work of Ahmad $e t$ al. (1994), who used recombinant chimeric forms of human PRPP synthase isozymes to implicate amino acid residues 17,18 and/or 41 as determining differences in the susceptibility of the isozymes to thermal denaturation and inactivation by proteolytic digestion.

\section{ACKNOWLEDGEMENTS}

We thank B. Bachmann and $\mathrm{K}$. Hammer for kindly providing bacterial strains, and Tonny D. Hansen for excellent technical assistance. This work was supported by National Institutes of Health Grant no. GM47112 to R. L.S. and by grants from the Danish Research Academy and the Danish Centre of Microbiology to B. H.-J.

\section{REFERENCES}

Ahmad, I., Ishijima, S., Kita, K. \& Tatibana, M. (1994). Identification of amino-acid residues linked to different properties of phosphoribosylpyrophosphate synthetase isoforms I and II. Biochim Biophys Acta 1207, 125-133.

Birnboim, H. C. \& Doly, J. (1979). A rapid alkaline extraction procedure for screening recombinant plasmid DNA. Nucleic Acids Res 7, 1513-1523.

Bolivar, F., Rodriguez, R. L., Greene, P. J., Betlach, M. C., Heynecker, H. L., Boyer, H. W., Crosa, J. H. \& Falkow, S. (1977). Construction and characterization of new cloning vehicles. II. A multipurpose cloning system. Gene 2, 95-113.

Bower, S. G., Hove-Jensen, B. \& Switzer, R. L. (1988). Structure of the gene encoding phosphoribosylpyrophosphate synthetase (prs $A$ ) in Salmonella typhimurium. J Bacteriol 170, 3243-3248.

Bower, S. G., Harlow, K. W., Switzer, R. L. \& Hove-Jensen, B. (1989). Characterization of the Eschericbia coli prs A1-encoded mutant phosphoribosylpyrophosphate synthetase identifies a divalent cation-nucleotide binding site. J Biol Chem 264, 10287-10291. 
Clark, D. J. \& Maaløe, O. (1967). DNA replication and the division cycle in Escherichia coli. J Mol Biol 23, 99-112.

Grandoni, J. A., Switzer, R. L., Makaroff, C. A. \& Zalkin, H. (1989). Evidence that the iron-sulfur cluster of Bacillus subtilis glutamine phosphoribosylpyrophosphate amidotransferase determines stability of the enzyme to degradation in vivo. $J$ Biol Chem 264, 6058-6064.

Harlow, K. W. \& Switzer, R. L. (1990). Chemical modification of Salmonella typhimurium phosphoribosylpyrophosphate synthetase with $5^{\prime}$ (p-fluorosulfonylbenzoyl)adenosine. Identification of an active site histidine. J Biol Chem 265, 5487-5493.

Hendrickson, N., Allen, T. \& Ullman, B. (1993). Molecular characterization of phosphoribosylpyrophosphate synthetase from Leishmania donovani. Mol Biochem Parasitol 59, 15-28.

Hove-Jensen, B. (1983). Chromosomal location of the gene encoding phosphoribosylpyrophosphate synthetase in Escherichia coli. J Bacteriol 154, 177-184.

Hove-Jensen, B. (1985). Cloning and characterization of the prs gene encoding phosphoribosylpyrophosphate synthetase of Escherichia coli. Mol \& Gen Genet 201, 269-276.

Hove-Jensen, B. (1988). Mutation in the phosphoribosylpyrophosphate synthetase gene (prs) that results in simultaneous requirements for purine and pyrimidine nucleosides, nicotinamide nucleotide, histidine and tryptophan in Escherichia coli. $J$ Bacteriol 170, 1148-1152.

Hove-Jensen, B. (1989). Phosphoribosylpyrophosphate (PRPP)less mutants of Escherichia coli. Mol Microbiol 3, 1487-1492.

Hove-Jensen, B. \& Nygaard, P. (1982). Phosphoribosylpyrophosphate synthetase of Escherichia coli. Identification of a mutant enzyme. Eur J Biochem 126, 327-332.

Hove-Jensen, B., Harlow, K. W., King, C. J. \& Switzer, R. L. (1986). Phosphoribosylpyrophosphate synthetase of Escherichia coli. Properties of the purified enzyme and primary structure of the prs gene. $J$ Biol Chem 261, 6765-6771.

Jochimsen, B. U., Hove-Jensen, B., Garber, B. B. \& Gots, J. S. (1985). Characterization of a Salmonella typhimurium mutant defective in phosphoribosylpyrophosphate synthetase. J Gen Microbiol 131, 245-252.

Kohara, Y., Akiyama, K. \& Isono, K. (1987). The physical map of the whole $E$. coli chromosome: application of a new strategy for rapid analysis and sorting of a large genomic library. Cell 50, 495-508.

Kushner, S. R., Nagaishi, H., Templin, A. \& Clark, A. J. (1971). Genetic recombination in Escherichia coli: the roles of exonuclease I. Proc Natl Acad Sci USA 68, 824-827.

Lupski, J. R., Ruiz, A. A. \& Godson, G. N. (1984). Promotion, termination, and anti-termination in the $r p s U$-dnaG-rpoD macromolecular synthesis operon of E. coli K-12. Mol \& Gen Genet 195, 391-401.

Mandel, M. \& Higa, A. (1970). Calcium-dependent bacteriophage DNA infection. $J$ Mol Biol 53, 159-162.

Miller, J. H. (1972). Experiments in Molecular Genetics. Cold Spring Harbor, NY: Cold Spring Harbor Laboratory.

Nilsson, D. \& Hove-Jensen, B. (1987). Phosphoribosylpyrophosphate synthetase of Bacillus subtilis. Cloning, characterization and chromosomal mapping of the prs gene. Gene 53, 247-255.
Nilsson, D., Arnvig, K. \& Hove-Jensen, B. (1989). Primary structure of the tms and prs genes of Bacillus subtilis. Mol $\mathcal{E}$ Gen Genet 218, 565-571.

Pandey, N. K. \& Switzer, R. L. (1982). Mutant strains of Salmonella typhimurium with defective phosphoribosylpyrophosphate synthetase activity. $J$ Gen Microbiol 128, 1863-1871.

Post, D. A. \& Switzer, R. L. (1991). prsB is an allele of the Salmonella typhimurium prs $A$ gene: characterization of a mutant phosphoribosylpyrophosphate synthetase. J Bacteriol 173, 1978-1986.

Post, D. A., Hove-Jensen, B. \& Switzer, R. L. (1993). Characterization of the bemA-prs region of the Escherichia coli and Salmonella typhimurium chromosomes: identification of two open reading frames and implications for prs expression. $J$ Gen Microbiol 139, 259-266.

Roessler, B. J., Bell, G., Heidler, S., Seino, S., Becker, M. \& Palella, T. D. (1990). Cloning of two distinct copies of human phosphoribosylpyrophosphate synthetase cDNA. Nucleic Acids Res 18, 193.

Sambrook, J., Fritsch, E. F. \& Maniatis, T. (1989). Molecular Cloning: a Laboratory Manual, 2nd edn. Cold Spring Harbor, NY: Cold Spring Harbor Laboratory.

Sanger, F., Nicklen, S. \& Coulson, A. R. (1977). DNA sequencing with chain-terminating inhibitors. Proc Natl Acad Sci USA 71, 5463-5467.

Shine, J. \& Dalgarno, L. (1974). The $3^{\prime}$-terminal sequence of Escherichia coli $16 \mathrm{~S}$ ribosomal RNA: complementarity to nonsense triplets and ribosome binding sites. Proc Natl Acad Sci USA 74, 1342-1346.

Silhavy, T. J., Berman, M. L. \& Enquist, L. W. (1984). Experiments with Gene Fusions. Cold Spring Harbor, NY: Cold Spring Harbor Laboratory.

Smith, P. K., Krohn, R. I., Hermanson, G. T., Mallia, A. K., Gartner, F. H., Provenzano, M. D., Fujimoto, E. K., Goeke, N. M., Olson, B. J. \& Klenk, D. C. (1985). Measurement of protein using bicinchoninic acid. Anal Biochem 150, 76-85.

Switzer, R. L. \& Gibson, K. J. (1978). Phosphoribosylpyrophosphate synthetase (ribose-5-phosphate pyrophosphokinase) from Salmonella typhimurium. Methods Envymol 51, 3-11.

Taira, M., Ishijima, S., Kita, K., Yamada, K., lizasa, T. \& Tatibana, $M$. (1987). Nucleotide and deduced amino acid sequences of two distinct $\mathrm{cDNAs}$ for rat phosphoribosylpyrophosphate synthetase. $J$ Biol Chem 262, 14867-14870.

Taira, M., liaza, T., Shimada, H., Kudoh, J., Shimizu, N. \& Tatibana, M. (1990). A human testis-specific mRNA for phosphoribosylpyrophosphate synthetase that initiates from a non-AUG codon. $J$ Biol Chem 265, 16491-16497.

Valentin-Hansen, P., Svenningsen, B. A., Munch-Petersen, A. \& Hammer-Jespersen, K. (1978). Regulation of the deo operon in Escherichia coli. The double negative control of the deo operon by the $c y t \mathrm{R}$ and $d e o \mathrm{R}$ repressors in a DNA directed in vitro system. Mol \& Gen Genet 159, 191-202.

Yanisch-Perron, C., Vieira, J. \& Messing, J. (1985). Improved M13 phage cloning vectors and host strains: nucleotide sequences of the M13mp18 and pUC19 vectors. Gene 33, 103-119.

Received 21 August 1995; accepted 28 September 1995. 